\title{
Brick and Glass Waste Valorisation in the Manufacture of Aerated Autoclaved Concrete
}

\author{
GEORGE STANESCU, ALINA BADANOIU*, ADRIAN NICOARA, GEORGETA VOICU \\ University Politehnica of Bucharest, Faculty of Applied Chemistry and Materials Science, 37 Polizu Str., 011061, Bucharest, \\ Romania
}

\begin{abstract}
Autoclaved aerated concrete $(A A C)$ is a light building material with high porosity, used to improve thermal and sound insulation of the buildings. AAC have a much better thermal efficiency than traditional masonry materials (bricks) or reinforced concrete elements; its use reduces the energy consumption (up to 7\%) and consequently the carbon footprint of construction sector. The main constituents of autoclaved aerated concretes are portland cement, siliceous material (aggregate), water and different types of admixtures and additives (lime, foaming agent etc.). The aim of the research presented in this paper is to reduce the environmental impact of the technological process of ACC manufacturing; in this respect, one of the main components of AAC i.e. sand (natural raw material) was substituted with two types of inorganic waste i.e. glass (cullet) and waste brick; the sand substitution rate was comprised between $12.5-100 \%$ wt. The results indicate that both glass and brick waste can be incorporated into the autoclaved aerated concrete (AAC) structure without major modifications of apparent density (maximum 10\% increase in correlation with substitution amount). For similar values of the apparent density, the AACs prepared with glass waste have higher values of compressive strength and thermal conductivity as compared with AAC with brick waste.
\end{abstract}

Keywords: autoclaved aerated concrete, glass waste, brick waste, properties

Autoclaved aerated concrete $(A A C)$ is a light building material with high porosity (60-90\%) [1,2]; due to it's specific microstructure (not connected, round pores), AAC have low thermal conductivity and can be used for fire resistant thermal insulations of buildings. The use of AAC improves the energy efficiency of buildings (energy consumption can be reduced up to $7 \%[3,4]$ ) and reduces the carbon footprint of residential sector.

AAC is produced by the mixing with water of cement, lime, gypsum, fine siliceous material (aggregate) and foaming agent (usually aluminum powder); the resulted slurry is cast in molds and hardened for several hours in order to expand and to achieve an adequate value of mechanical strength. This material is then shaped (cut) in blocks and cured for $10-12 \mathrm{~h}$ at $120^{\circ} \mathrm{C}$ and $12 \mathrm{~atm}$. The resulted product (AAC) has low densities $\left(300-550 \mathrm{~kg} / \mathrm{m}^{3}\right)$ and compressive strength values comprised between 2-7 $\mathrm{N} / \mathrm{mm}^{2}[2,3]$.

In the past 30 years, numerous studies were performed in order to reduce the carbon footprint of Portland cement and derived concrete, by the partial replacement of clinker with various mineral admixtures [4-8]; today the production portland cements/concretes with supplementary cementitious materials such as slag, fly ash, limestone filler etc. is a current practice in world-wide cement and concrete industries.

In AAC production one of the main research topics was to identify eco friendly and cost-effective alternative raw materials for the partial substitution of siliceous component (sand) or/and cement. Numerous types of mineral admixtures or wastes, such as - zeolite [9], rice husk ash [10], gasification residues [11], waste bricks [12], coal bottom or fly ash $[13,14]$, copper tailings and blast furnace slag [15] etc, - were studied. As expected, the replacement of quartz sand with the above mentioned materials modifies, in various extent, the main properties of AAC i.e. density, mechanical strength and thermal conductivity.
In this context, the main objective of this research work was to study the influence, on the main properties, of replacing the siliceous component (quartz sand) with two type of industrial wastes ( glass cullet and red brick waste) available in adequate quantities in the proximity of an $A A C$ production plant.

\section{Experimental part}

The materials used to obtain the autoclaved aerated concrete (AAC) were:

-ground crystalline sand with the following characteristics: $5 \%$ moisture, $1 \%$ leachable material content (determined according to SR EN 933-1), fineness corresponding to a residue on a 90 microns mesh sieve of $8 \%$;

-portland cement- CEM I 52,5 R (according to SR EN 197-1);

-lime - CL90 (SR EN 459-1: 2011) with a minimum CaO content of $90 \%$ and $\mathrm{MgO} \leq 5 \%$;

-calcium sulphate source (CS) - $80 \%$ and humidity-3.5\%; -AAC slurry - resulted by the milling of AAC waste and dispersion in water (slurry density $1.36 \mathrm{~kg} / \mathrm{l}$ )

- aluminium paste - foaming agent.

In this work the sand has been replaced with the following wastes:

-soda lime glass cullet (from a waste recycling plant) grounded up to a fineness corresponding to $10 \%$ residue on 90 microns mesh sieve; the degree of substitution of sand was $12.5 \%$ wt., $25 \% w t$., $50 \% w t$. and $100 \%$ wt.

-brick waste (technological waste of a local brick factory). The degree of substitution of sand with this waste was $25 \%$ wt and $100 \%$ wt.

Glass and brick wastes were milled in a laboratory ball mill. The mill was fed with equal amounts (wt.) of grinding bodies (balls) and glass/brick waste. The grain size distribution of the ground wastes was determined with a laser granulometer Matersizer 2000. 
1.

The flow chart of AAC manufacture is presented in figure

The properties determined on the hardened AACs (dried at $70 \pm 5)^{\circ} \mathrm{C}$ up to constant mass, were:

- apparent (geometric) density - assessed according to SR EN 772-13:2001 [16].

- compressive strength - assessed according to SR EN 772-1+A1 :2016 [17];

- thermal conductivity was determined according to the method presented in the SR EN 1745:2012 [18];

The mineralogical composition of the raw materials and ACCS was assessed by X-ray diffraction (XRD) (PANanalytical Empyrean type with CuK $\alpha-\lambda=0.154 \mathrm{~nm}$ ) and the microstructure was evaluated by scanning electronic microscopy (SEM) using a high-resolution scanning electron microscope equipped with a Schottky field electron beam source (FEI InspectF50) provided with the EDX.

\section{Results and discussions}

Processing and characterization of wastes used for partial/ total replacement of ground sand in autoclaved aerated concrete composition

The variation of wastes' fineness (residue on 90 microns mesh sieve- $\left.R_{009}\right)$ vs. the grinding time is presented in figure 2.

According to the data presented in figure 2 the sodalime glass waste reaches the desired fineness $\left(R_{009} \leq 10 \%\right)$ after 25 hours of grinding; in the case of brick waste, the grinding process is less effective and after $40 \mathrm{~h}$ of grinding the material has a much smaller fineness $\left(R_{009}=27 \%\right)$. This can be explained by the higher temperatures at which the bricks are processed in modern plants as compared to bricks produced by traditional methods; this results in porosity reduction and consequently the increase of mechanical strength [19-21].

The grain size distribution curves presented in figure 3 reveal a series of differences between the ground sand and wastes (glass and brick).

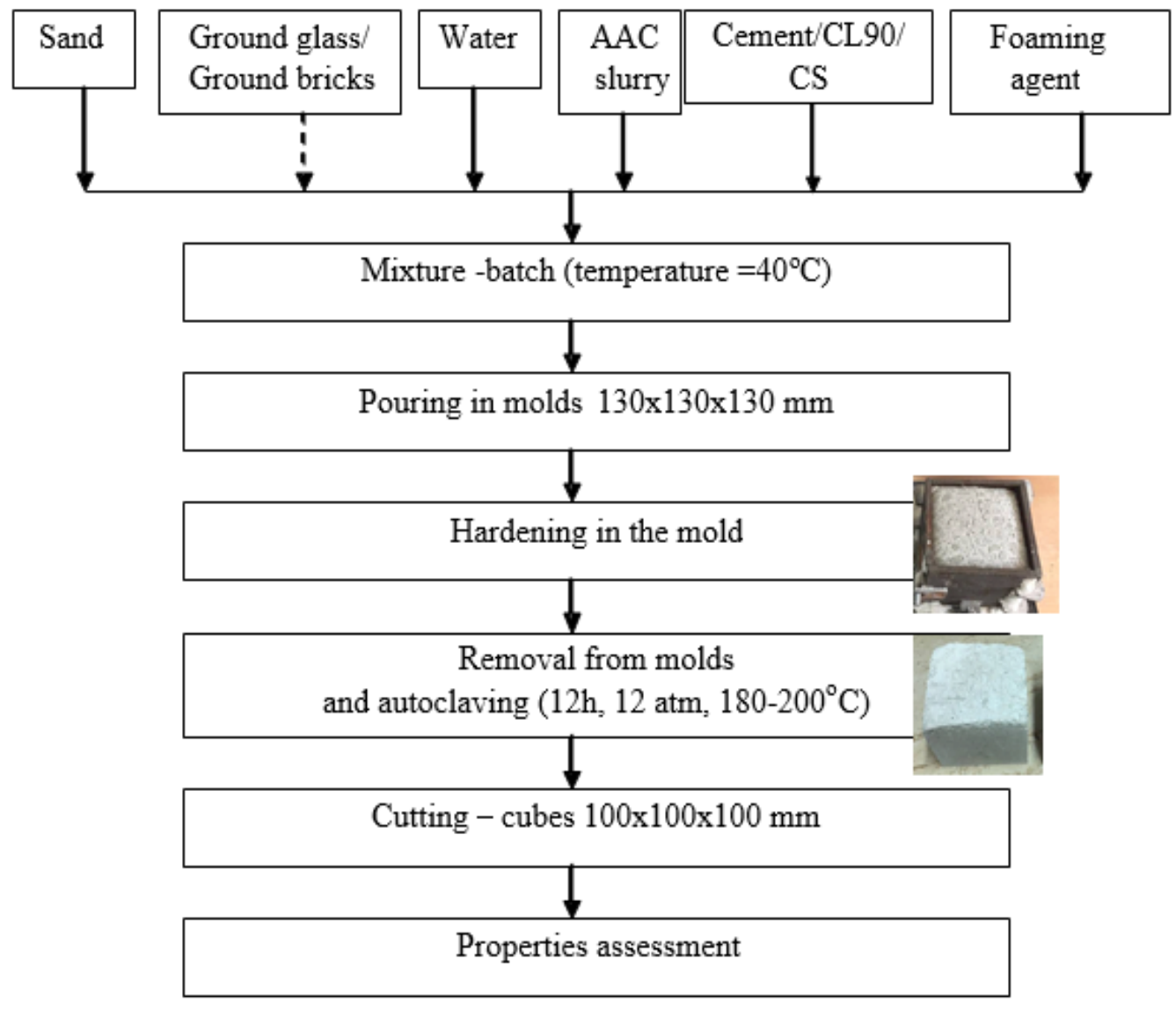

Fig. 1. Flow chart of $A A C$ manufacture

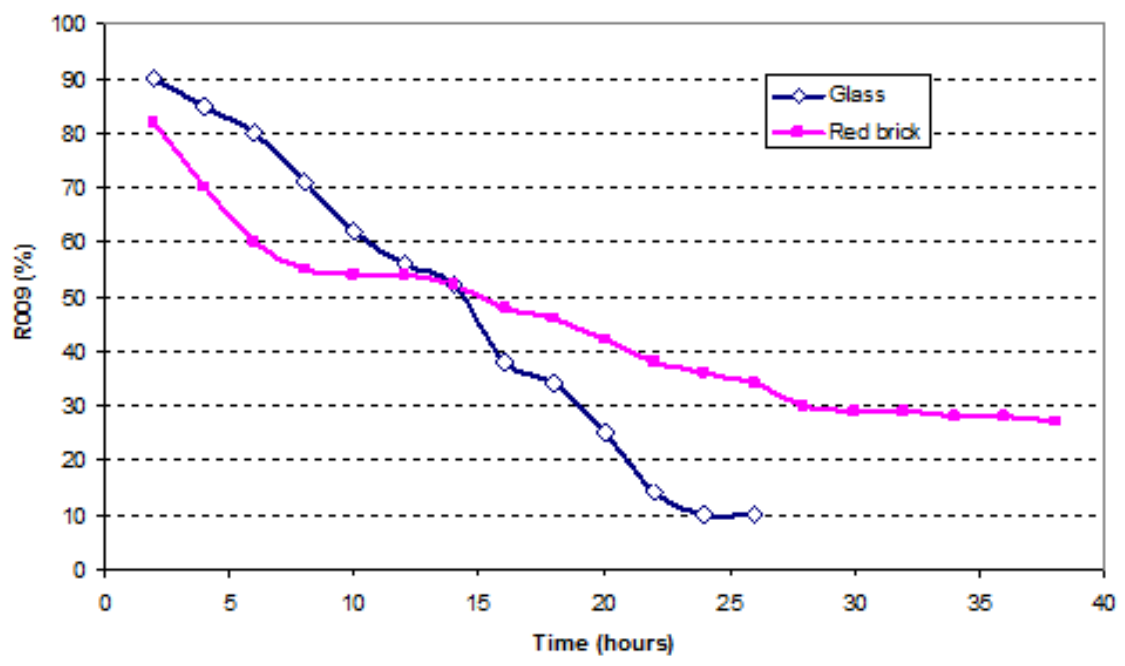

Fig. 2. Residue on 90 microns mesh sieve vs. grinding time in ball mill 


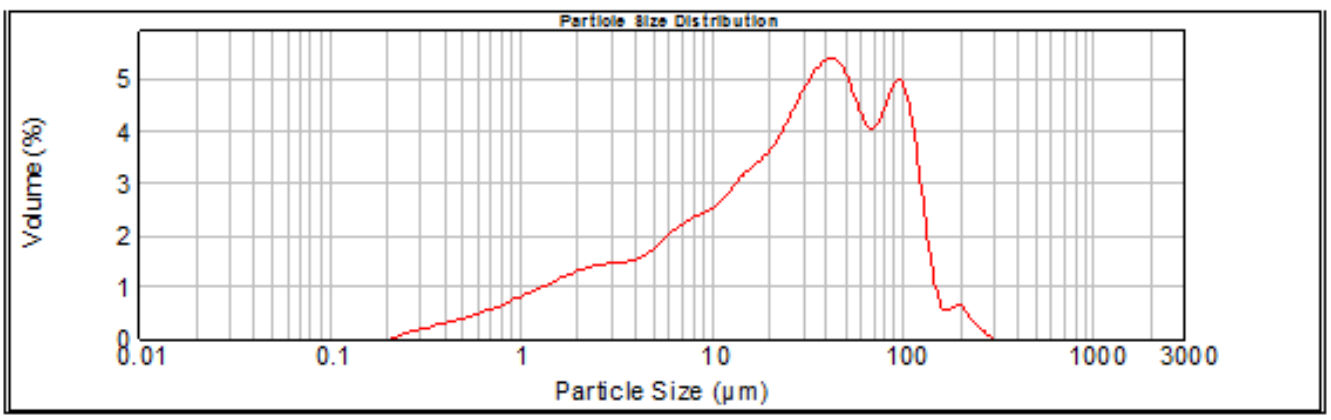

a)

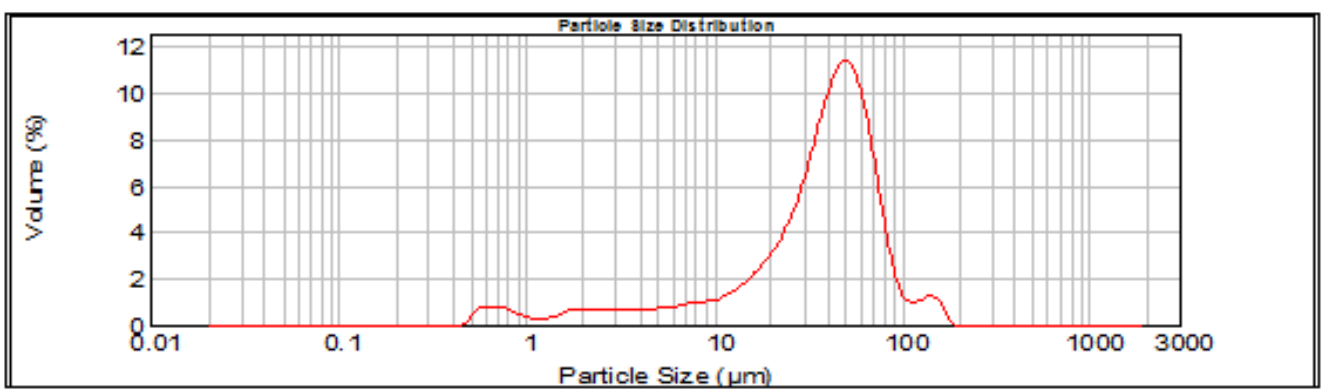

Fig. 3. Particle size distribution for ground sand (a), waste glass powder (b) and red brick powder (c)

b)

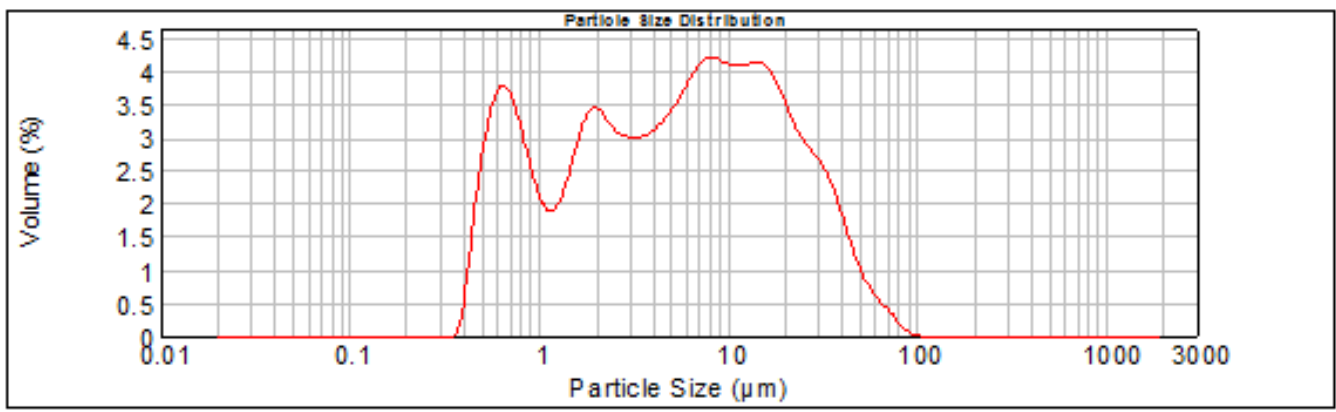

c)

In the case of sand, one can assess a high amount of particles with sizes comprised between 40 microns and 90 microns (fig. 3a). For glass powder the largest share is represented by the particles with the average size of 14 microns and in the case of brick powder, the grain size distribution is discontinuous with several grain size fractions i.e. average particle size of 0.65 microns, 2 microns, 8 microns and 10.5 microns.

The microstructure of the milled materials was assessed by scanning electron microscopy-SEM (fig. 4).

The micrographs presented in figure 4 show the presence, for all studied materials, of particles with sharp edges and corners which are specific for the materials obtained by grinding. In the case of brick powder (fig.4c,d), a larger amount of smaller particles can be observed, in good agreement with the previously presented grain size distribution analyzes (fig. 3). It can be also noticed, a certain agglomeration of the smaller particles on the surface of the larger particles - this could also explain why the grinding of this material is more difficult; Liu et al. [22] explain this phenomenon, by the formation of a layer of small secondary particles on the surface of larger particles which can prevent the impact with grinding balls or other larger granules, i.e. the process responsible for material crushing.

The elemental composition of the raw materials is presented in table 1 and the mineralogical composition of the ground sand and the brick waste powder are show $n$ in figure 5 .

According to the data presented in table 1, waste brick powder have a lower silica content compared with ground sand and glass powder. As expected, the soda-lime glass powder has high sodium content.

$X$-ray diffraction patterns presented in figure 5 a confirms the presence of quart (Q-PDF 83-2465) and albite - (Alb-
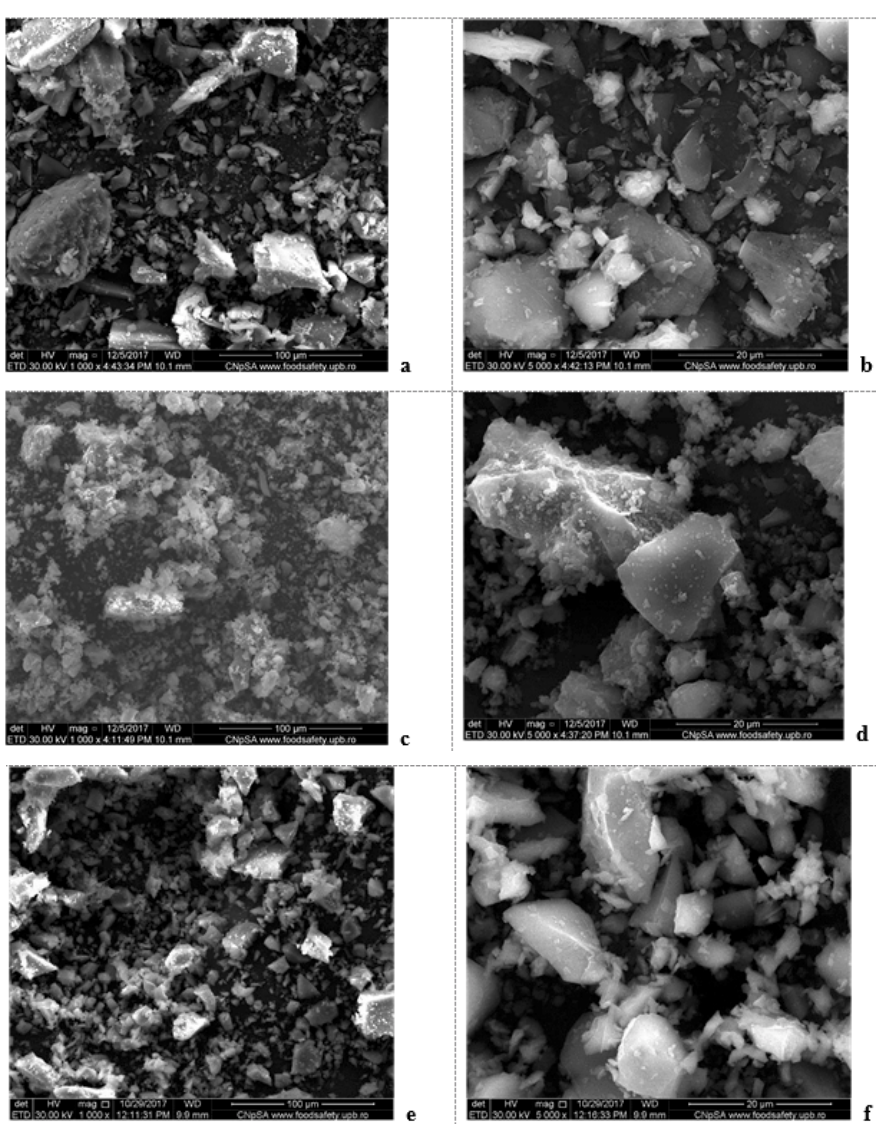

Fig. 4. SEM micrographs of ground sand $(a, b)$, waste brick powder $(c, d)$ and waste glass powder $(e, f)$ PDF 76-0758) - clay impurity, in the natural sand. The XRD 
Table 1

ELEMENTAL COMPOSITION ASSESSED BY EDX

\begin{tabular}{|c|c|c|c|}
\hline Element & Sand & Brick & Glass \\
\hline $\mathrm{Si}$ & 34.67 & 19.00 & 30.38 \\
\hline $\mathrm{Al}$ & 2.76 & 8.47 & 1.97 \\
\hline $\mathrm{Ca}$ & 2.73 & 4.07 & 5.56 \\
\hline $\mathrm{Na}$ & 1.82 & 1.60 & 12.89 \\
\hline $\mathrm{Fe}$ & 1.57 & 3.60 & nd \\
\hline $\mathrm{K}$ & 0.52 & 2.04 & nd \\
\hline $\mathrm{Mg}$ & 0.39 & 2.12 & 1.52 \\
\hline
\end{tabular}

nd- not detected

patterns of brick waste powder (fig. 5b), shows the presence of quartz (Q-PDF 83-2465) and anorthite (A-PDF 73-0264); the presence of halo in the $2 \theta=20-40$ degrees range, suggests, as expected, the presence of a phase with a low degree of crystallinity.
The influence of partial/total sand substitution with different types of waste on the main AAC properties

Figure 6 shows the influence of sand partial/total substitution with glass and brick waste powder on the AACs apparent density.

The partial/total substitution of sand with glass/brick waste pow der causes a slight increase (up to $10 \%$ ) of AACs apparent density.

As expected, the apparent density of AACs has an important influence on other properties - compressive strength and thermal conductivity (fig. 7); the values of compressive strength and thermal conductivity increase with the increase of AACs apparent density.

The partial substitution of sand with waste glass powder leads to the increase of compressive strength and thermal conductivity in good correlation with density increase.

The substitution of sand with of waste brick powder determines a decrease of compressive strength values (compared to the AAC with glass with the same value of apparent density). This can be explained by the reduction of $\mathrm{Si}\left(\mathrm{SiO}_{2}\right)$ content in AAC composition when the degree of substitution of sand with waste brick powder increases (table 1); consequently, a lower amount of calcium silicates
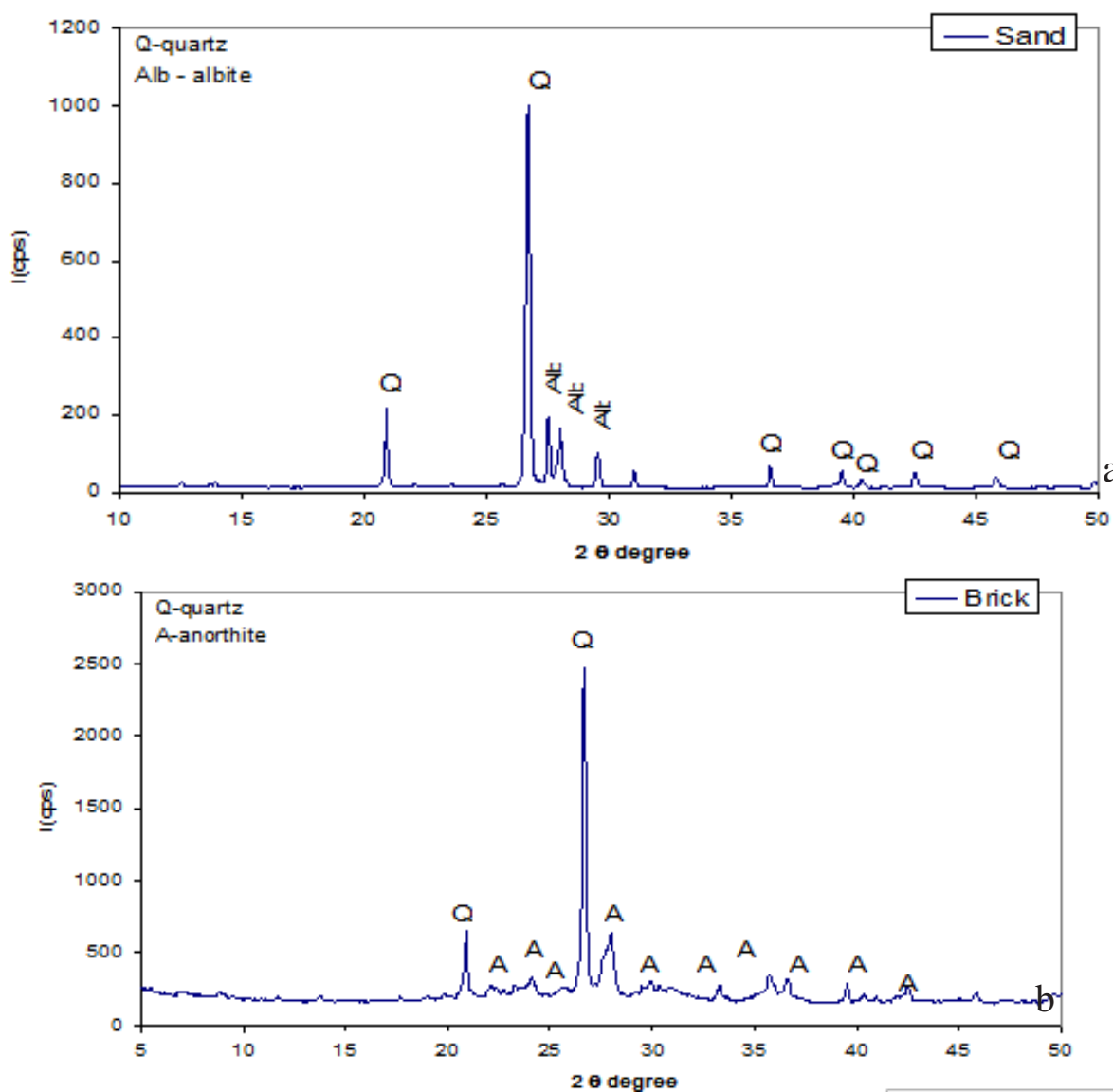

Fig. 5. XRD patterns of sand (a) and waste brick (b)

Fig. 6. Influence of partial/total substitution of sand in ACC composition with glass and brick waste

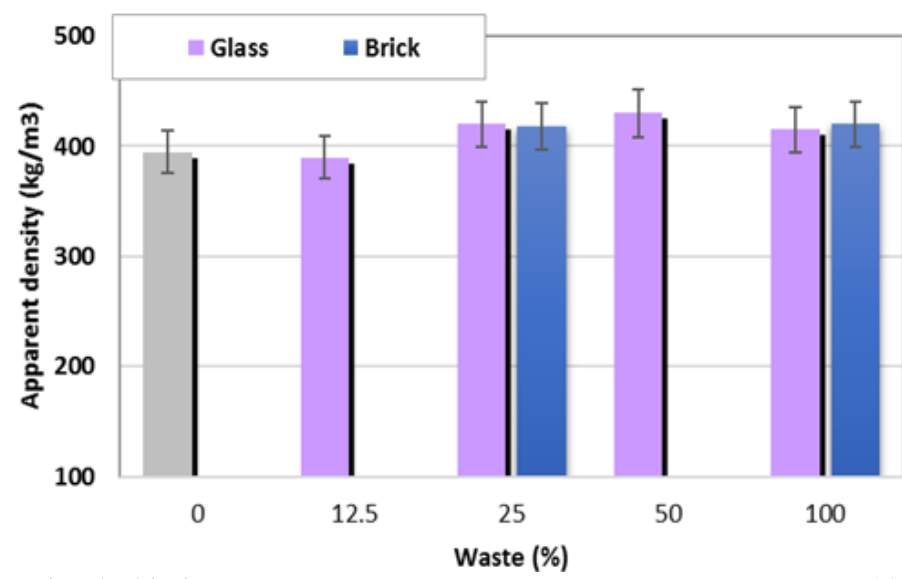



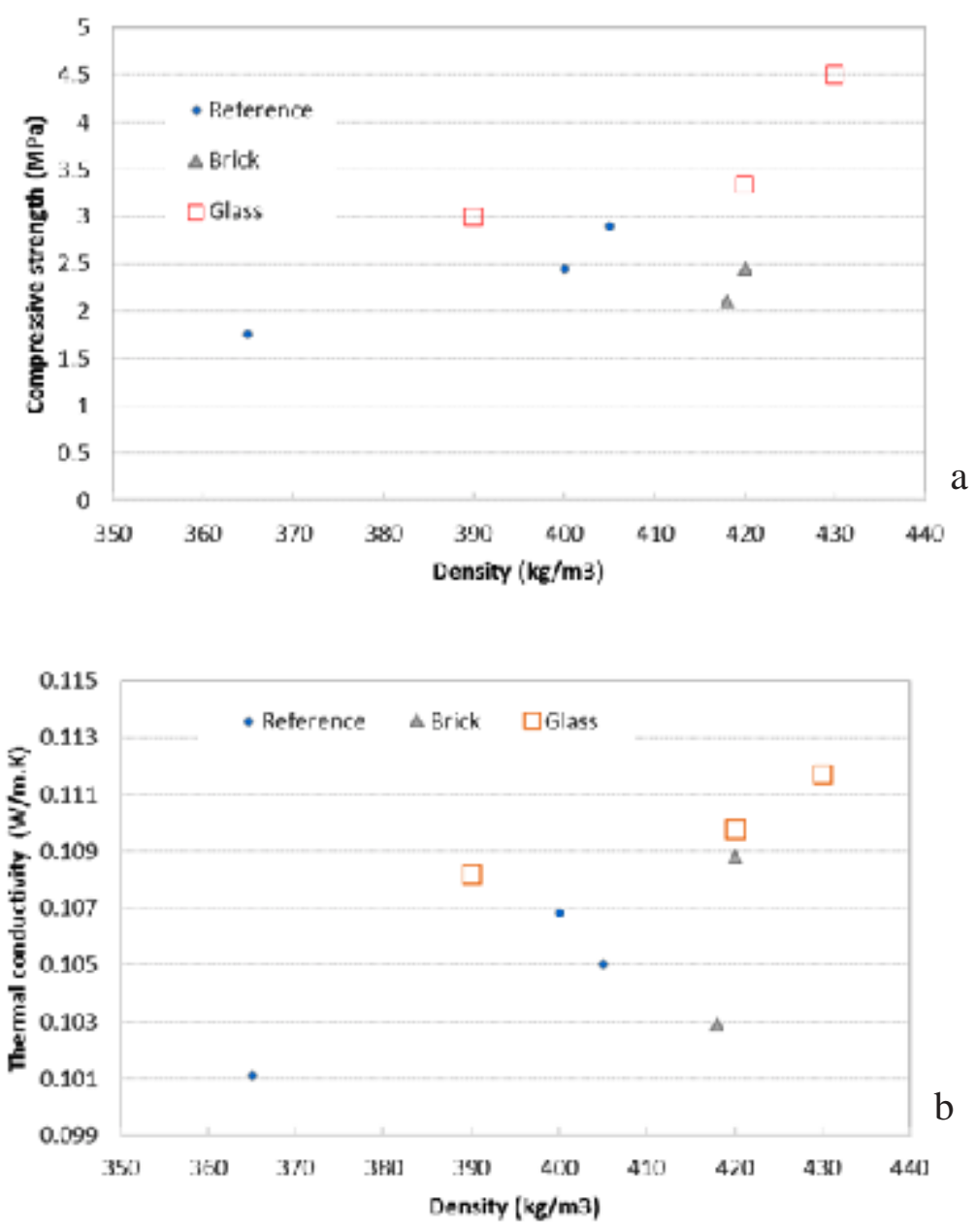

Fig. 7. Variation of compressive strength (a) and thermal conductivity (b) vs. the apparent density of AAC hydrates (hydrates responsible for increase of compressive strengths) will be formed in these formulations.

The X-ray diffraction patterns, presented in figure 8, provide information on the mineralogical composition of the autoclaved aerated concrete in which sand is totally substituted with waste brick/glass powders.

On the XRD patterns of ACC prepared with sand (Ref), are present the peaks specific for tobermorite T(PDF-060012) which results in the reaction of portlandite with reactive silica available in the system; the presence of XRD peaks specific for quartz $\left(\mathrm{SiO}_{2}\right)$ suggests its partial consumption in the above-mentioned reaction.

The XRD patterns of ACC formulation in which the sand is completely substituted with brick waste powder (Brick 100) highlights also the presence of quart and tobermorite.
For the AAC prepared with waste glass powder (Glass $100)$, one can assess on the XRD patterns only the peaks specific for tobermorite; this was to be expected given the vitreous state of silica from glass (not detectable by XRD method).

SEM images and EDX analysis of studied AACs are presented in figures 9-11.

On the SEM image of reference (ACC with $100 \%$ sand fig. 9a) one can assess the presence of closed and large pores (ranging from 0.5 to $2 \mathrm{~mm}$ ); at a higher magnification (fig. 9c) one can notice the presence of needle like or platelike (foils) crystals, which can be attributed to tobermorite $[13,15,23]$; EDX spectrum (fig. 9d - corresponding to the area from fig. 9c) confirms the presence of $\mathrm{Ca}$ and $\mathrm{Si}$, in high amounts, in these phases.

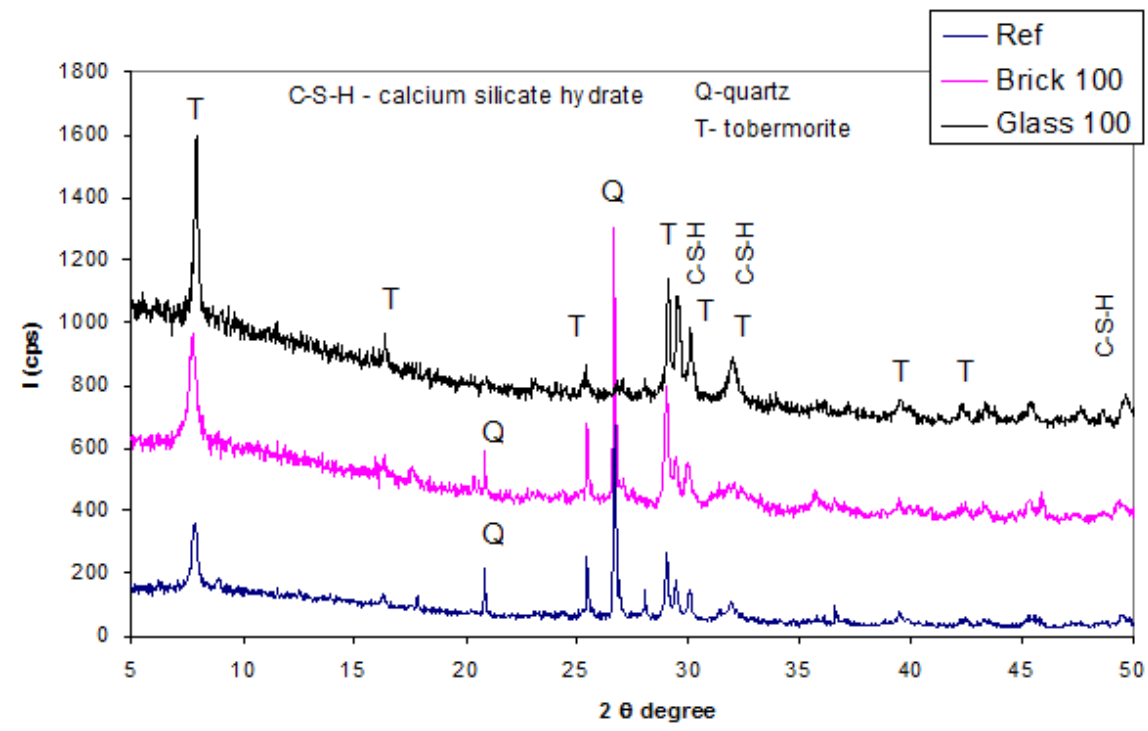

Fig. 8. XRD patterns of ACCS formulations with sand (Ref), waste brick (Brick 100) and waste glass powder (Glass 100) 

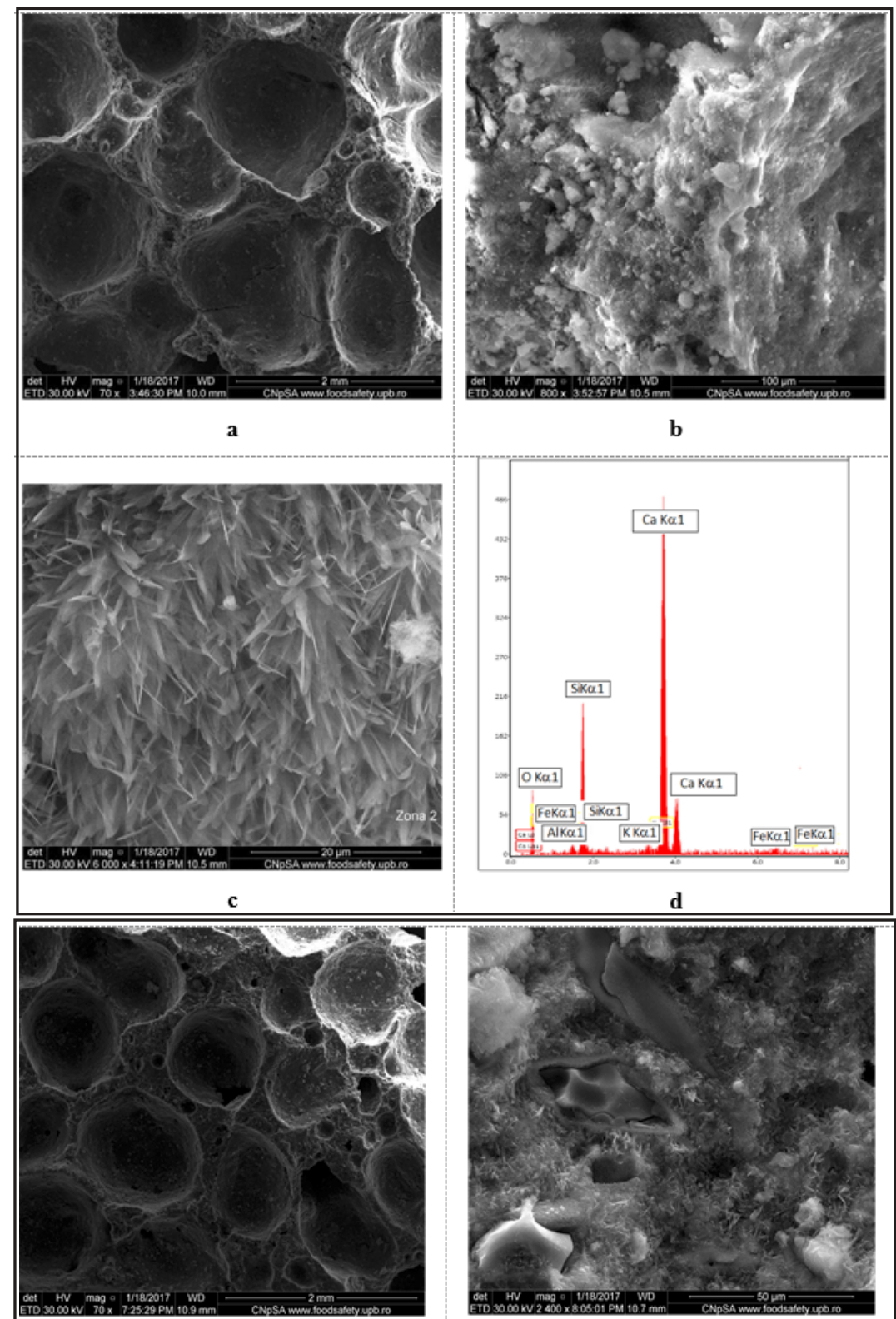

a

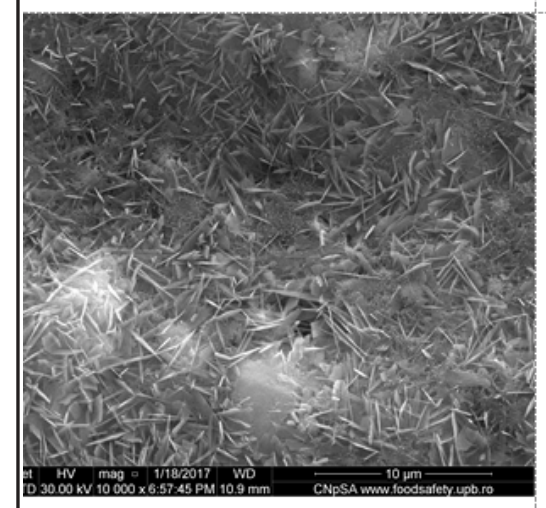

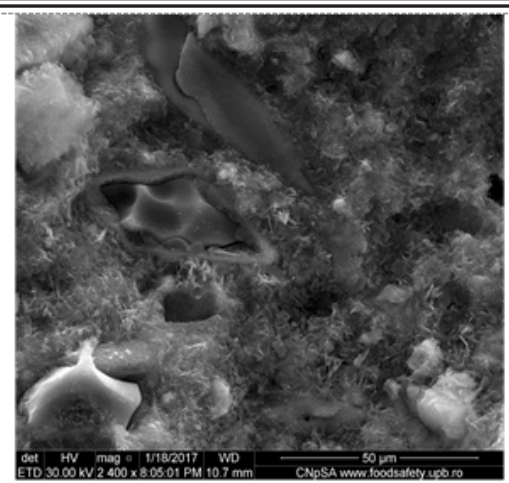

b

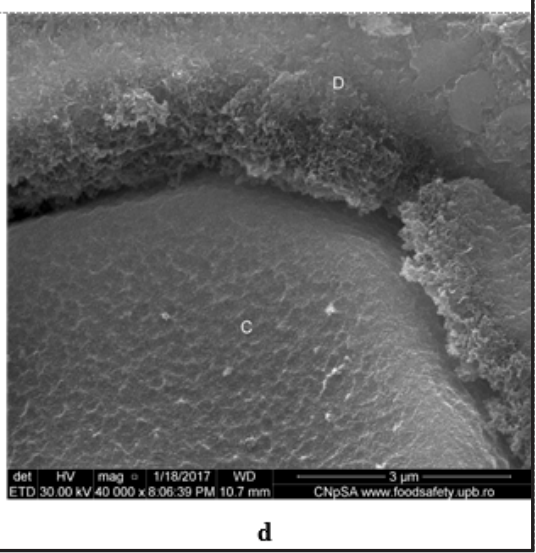

Fig. 9. SEM images $(a, b, c)$ and corresponding EDX spectrum $(d)$ of reference (AAC with $100 \%$ sand)
In the SEM images of the ACC with $100 \%$ waste glass powder (fig. 10), one can assess in the presence of glass particles (with sharp edges and corners - see also fig.10b,c), embedded in a binding matrix consisting of needle like calcium silicates hydrates (tobermorite); one can also notice the rough surface of glass particle (fig. 10d) suggesting its superficial dissolution.

The images of AAC with $100 \%$ wt. waste brick powder (fig. 11), show a good incorporation of the brick particles in the binding matrix (fig.11b, c) as well as the presence of the needle-like (fig.11c) and plate-like (fig.11d) crystals, specific for tobermorite [10,11,24]. The higher amount of plate-like crystals formed in this AAC (as compared with the previous ones) can be explained by the lower amount of reactive $\mathrm{Si}\left(\mathrm{SiO}_{2}\right)$; according to Kunchariyakun et. al. [10] the microstructure of calcium silicates hydrates is influenced by silica amount and reactivity i.e. the increase of $\mathrm{Ca} / \mathrm{Si}$ ratio determines the change of the fibrous, needlelike crystals in plate-like (crumbled foils); therefore, the substitution of sand with brick waste (with a smaller 


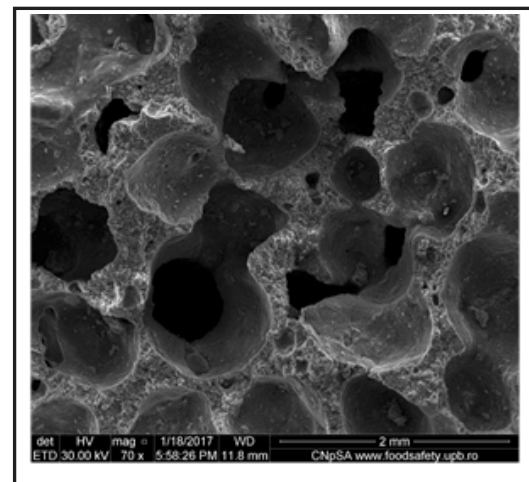

$\mathbf{a}$

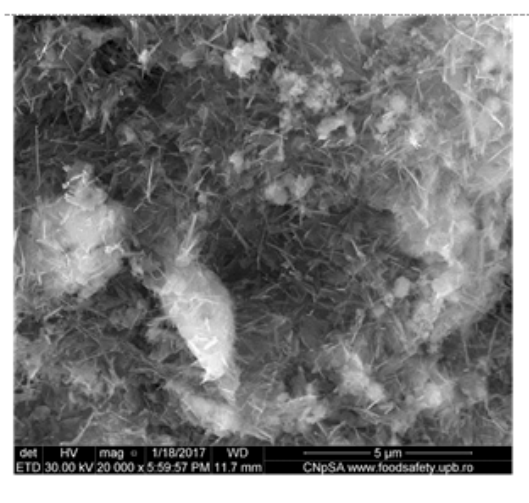

c

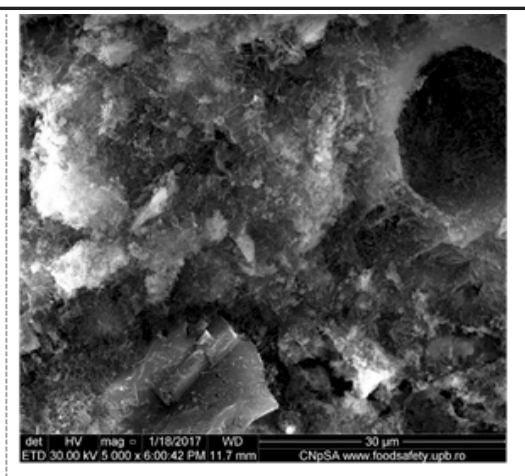

b

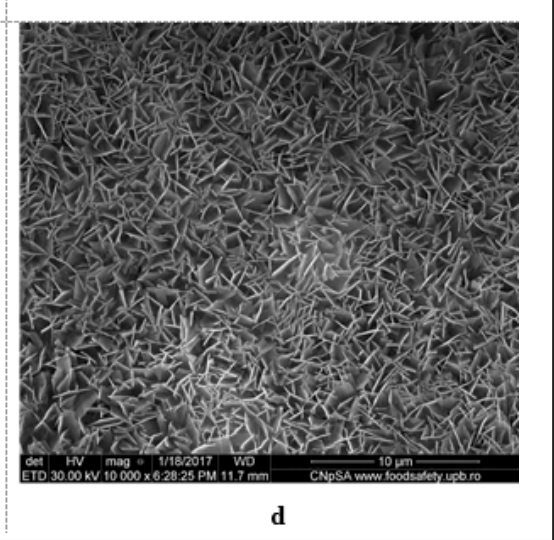

Fig. 11. SEM images $(a, b, c, d)$ of AAC with $100 \%$ brick waste pow der (100 Brick) silicium content, table 1) favours the formation of platelike (crumbled foils) crystals.

\section{Conclusions}

The results indicate that both glass and brick waste can be incorporated into the autoclave aerated concrete (AAC) structure without major modifications of apparent density (maximum $10 \%$ increase).

The partial substitution of sand with waste glass powder leads to the increase of compressive strength and thermal conductivity in good correlation with density increase.The sand substitution with brick waste determines the decrease of compressive strengths.

The AAC microstructure is influenced by the presence of glass and brick wastes; the morphology of the main hydrate formed in AAC i.e. tobermorite - needle-like and plate-like crystals - is correlated with the amount and reactivity of $\mathrm{SiO}_{2}$ in the starting mixture.

\section{References}

1. GHAZI WAKILI K., HUGI E., KARVONEN L., SCHNEWLIN P., WINNEFELD F., Cement \& Concrete Composites 62, 2015, p.52-55 2. CHAIPANICH A., CHINDAPRASIRT P., The properties and durability of autoclaved aerated concrete masonry blocks in Eco-efficient Masonry Bricks and Blocks, Elsevier Press, 2015

3. RADHI H., Energy and Buildings, 43, 2011, p.2086-2092.

4. SAMAD S., SHAH A., International Journal of Sustainable Built Environment 6, 2017, p.663-674

5. BADANOIU, A., MUSTATEA, F., VOICU, G., Rev. Chim.(Bucharest), 64, 2013, p.1015-1020

6. HOOI JUN, N. , MINCIUNA, N.G., AL BAKRI ABDULLAH, M.M., JIN, T.S., SANDU, A.V., MING, L.Y., Rev. Chim.(Bucharest), 68, no. 10, 2017, p.2367-2372

7. CHENDES, R., BOB, C., BADEA, C., PODOLEANU, C.E., DAN, S., IURES, L., Rev. Chim.(Bucharest), 67, no.8, 2016, p. 1868-1871
8. BARBULESCU L., BADANOIU A.,NICOARA A., PIRVU C., Romanian J ournal of Materials, 47, 2017, p.16-23

9. ALBAYRAK M, YORUKOGLU A., KARAHAN A, ATLIHAN S, YILMAZ ARUNTAS H., GIRGIN I, Building and Environment 42, 2007, p. 31613165

10. KUNCHARIYAKUN K., ASAVAPISIT S., SOMBATSOMPOP K., Cement $\&$ Concrete Composites, 55, 2015, p.11-16

11. HOLT E., RAIVIO P., Cement and Concrete Research 35, 2005, p. 796- 802

12. ALIABDO A, ABD-ELMOATY M., HASSAN H., Alexandria Engineering Journal 53, 2014, p.119-130

13. WONGKEO W., THONGSANITGARN P., PIMRAKSA K., CHAIPANICH A., Materials and Design 35, 2012, p. 434-439

14. DROCHYTKA R., ZACH J., KORJENIC A., HROUDOVA J., Energy and Buildings, 58, 2013, p.319-323

15. HUANG X., NI W, CUI W., WANG Z., ZHU L., Construction and Building Materials 27,2012 , p. 1-5

16.*** SR EN 772-13:2001- Methods of test for masonry units - Part 13: Determination of net and gross dry density of masonry units (except for natural stone)

17. *** SR EN 772-1+A1 :2016, Methods of test for masonry units - Part 1: Determination of compressive strength

18. *** SR EN 1745:2012 - Masonry and masonry products. Methods for determining thermal properties

19. KARAYANNIS V., NTAMPEGLIOTIS K., LAMPRAKOPOULOS L., KASITEROPOULOU D., PAPAPOLYMEROU G., SPILIOTISX., Romanian Journal of Materials, 46, 2016, p.523 - 529

20. KARAMAN S., ERSAHIN S., GUNAL H., J ournal of Scientific and Industrial Research, 65, 2006, p. 153-159.

21. LAEFER D.F., BOGGS ., COOPER N., J ournal of American Institute for Conservation (JIAC), 43, 2004, p. 255-272)

22. LIU S., LI Q., XIE G., LI L., XIAO H., Powder Technology, 295, 2016, p.133-141

23. GEORGESCU M., PURI A., Chemistry of Inorganic Binders (in Romanian), Ed. Politehnica Press, Bucharest, 2004

Manuscript received: 13.04 .2018 